\title{
Diatom diversity and organic matter sources in water bodies around Chennai,Tamil Nadu, India
}

\begin{abstract}
In the present study, sediment samples were collected from different locations and diverse environments around Chennai city to evaluate the environmental conditions and the health of the water bodies. The grain size analysis of the sediment samples reveals that sand is the dominant fraction deposited in high-energy coastal environments followed by silty sand, sandy silt, while as the sediment samples of Cooum River and fresh water lakes and Buckingham canal show the dominance of silty clay and clayey silt respectively. The $\mathrm{C} / \mathrm{N}$ ratio of the sediment samples indicates in situ source of algal organic matter, except Cooum River, while the confluence of the Cooum River to the sea and the Buckingham canal exhibits dominant terrestrial source of organic matter. Significant positive correlation of clay with $\mathrm{TOC}, \mathrm{C} / \mathrm{N}$ ratio signifies strong binding of these elements with finer clay particles. Predominant occurrences of diatom species such as Cyclotella striata, Navicula and Nitzchia linearis in the water bodies of Chennai shows high organic pollution caused by anthropogenic influences.
\end{abstract}

Keywords: diatom, C/N ratio, sediment texture, TOC, TN, anthropogenic influences
Volume 2 Issue 3 - 2017

\author{
Aasif Ali, Nilli Avittom, Aasif Lone, Hema \\ Achyuthan, Rayees Shah \\ Department of Geology, Anna University, India
}

Correspondence: Hema Achyuthan, Department of Geology, Anna University, Chennai 600 025, India,

Tel 093-828-496-62, Email hachyuthan@yahoo.com

Received: March 01, 2017 | Published: June 16, 2017

\section{Introduction}

Freshwater ecosystems are crucial for human survival, central to ecological structure and function, and arguably the most valuable habitats on the landscape. They also serve as important sentinels of past environmental changes across multiple temporal and spatial scales. ${ }^{1}$ Sediment texture and its distribution are one of the most fundamental and pervasive method undertaken for the analysis of sediments and soils. ${ }^{2}$ Grain size analysis describes the sediment size distribution and provides environmental information as mechanism of how the sediments are deposited in different sedimentary basins. ${ }^{3}$ The particle grain size in water bodies is very sensitive to small changes in the catchment and the turbulence of water and wave energy is the main cause for grain size distribution in marine as well as in fresh water bodies. ${ }^{4}$ Carbon and nitrogen are continuously added to the sediments of aquatic ecosystems by mixing of terrestrial and autochthonous organic matter. ${ }^{5}$ Carbon and Nitrogen as nutrients play a vital role in maintaining tropic levels in different water bodies all over the world. The ratio of total organic carbon to total nitrogen $(\mathrm{C} / \mathrm{N}$ ratio) has been used as an indicator of the source of organic matter $(\mathrm{OM})$ in sediments. ${ }^{6}$ Diatoms are microscopic aquatic unicellular autotrophic eukaryotic algae having a cell wall made of silica (hydrated silicon dioxide) belonging to the Kingdom Protista and Class Bacillariophyceae. ${ }^{7}$ They are usually yellowish or brownish in color ranging in size from approximately 5 microns to 1000 microns and are found in fresh water and marine water in moist soil and on the surface of plants. ${ }^{8}$ They are important contributors to the primary productivity in aquatic ecosystems, sitting at the bottom of the food chain, but usually grow better in unpolluted ponds and streams and could be useful for biological monitoring of pollution levels and ecosystem integrity. ${ }^{9}$

Diatoms are used as indicators of water quality because of their short life span and quick response to the environmental changes. ${ }^{10}$ Great diversity of diatoms is found in the clean water, but only a few survive in polluted water with one or two dominant forms. ${ }^{11}$ Owing to the sensitivity to pollution or other changes in water chemistry, Diatoms are widely used for monitoring environmental contamination and serve as bio-indicator of water quality and pollution status. ${ }^{12}$ Nutrient loading due to anthropogenic activities is one of the most widespread and severe disturbances that are threatening the ecological health of present aquatic ecosystems. ${ }^{13}$ Diatoms are an effective proxy for environmental changes due to their sensitivity to a variety of ecological conditions, temperature, and light intensity and physiochemical characteristics of the environment such as $\mathrm{pH}$, salinity and the presence of organic matter. ${ }^{8}$ Diatoms usually are more sensitive to small variations in the environment as compared to other macrophytes and benthic algae. ${ }^{14}$ Thus, they are used to monitor sediment quality because the species found in a water body will inform about some characteristics of that ecosystem. ${ }^{15}$ Diatoms are used extensively in palaeo-ecological studies because they are excellent indicators of past environmental conditions. Proxy indicators, such as diatoms, provide a promising means for evaluating past ecosystem responses to climatic and environmental changes. ${ }^{16}$ For instance, transfer functions developed between diatom communities and water salinity has allowed the inference of drought conditions in prairie lakes in the mid-western U.S.A. ${ }^{17}$ The modem distribution and ecological relationships of diatoms can be used to interpret the environment in which the fossils of these organisms were once living. ${ }^{18}$ Increasing anthropogenic impact has complicated freshwater ecosystems due to overexploitation associated with geomorphic changes along the catchments. ${ }^{19}$ The use of various proxy records has enabled us to infer the environmental changes that have occurred during the last few decades coupled with anthropogenic impacts. The impetus behind studying such changes is to reconstruct the future changes and take up steps to further reduce the impact of such changes. The lake and other water bodies that have been sampled in the present study fall on the pathway of the dominant northeast monsoonal precipitation and hence any change in the intensity and the amount of this monsoon will reflect in the sediment texture, distribution, and the amount of OM delivered to these water bodies from diverse catchment sources. 
Hence, the main objective of the present study was to understand the source of $\mathrm{OM}$ and the diatom assemblage distribution to have a preliminary knowledge about the sediment pollution of these sites. For this purpose, sediment samples from diverse water bodies within Chennai city were collected and analysed for various textural, organic matter (OM), $\mathrm{C} / \mathrm{N}$ ratio and diatom assemblage.

Chennai is one of the four important metropolitan cities and is located on the southeastern coast of India, on a flat coastal plain known as the East Coast Plains (Figure 1). The average elevation is around 6.7 meters $(22 \mathrm{ft})$, and its highest point is $60 \mathrm{~m}(200 \mathrm{ft})$. Two major rivers drain the Chennai city, the Cooum River (or Koovam) passing through the centre and the Adyar River to the south. A third river, the Koratallaiyar, meanders through the northern fringes of the city before draining into the Bay of Bengal, at Ennore. The estuary of the Cooum and the Adyar rivers are heavily polluted with effluents released by the industries, and waste from domestic and commercial sources. The Buckingham Canal nearly $4 \mathrm{~km}$ (2.5mi) long inland, running parallel to the coast, and links these two rivers. The Otteri Nullah, an east-west stream, runs through north Chennai and meets the Buckingham Canal at the Basin Bridge. Several lakes of varying size are located on the western fringes of the city. The Adyar River carries the drainage and floodwater of Chennai city and its environs during the northeast monsoon period ${ }^{20}{ }^{20}$ while the Cooum River serves as drainage and sewerage carrier within the Chennai city limit. ${ }^{21}$
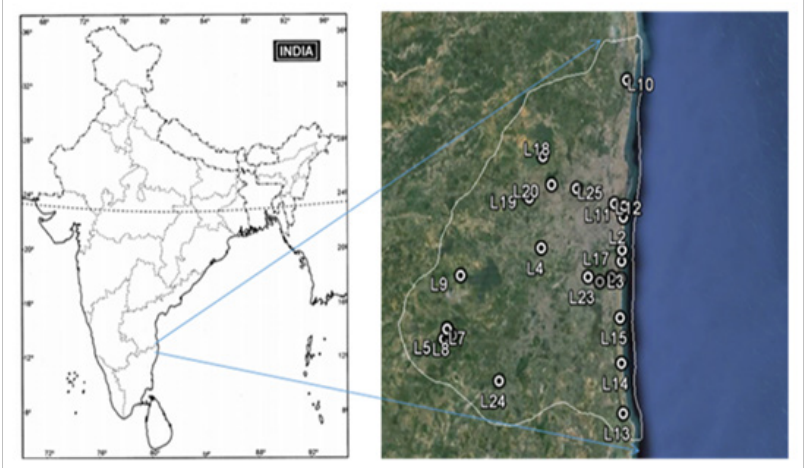

Figure I Location map of the study area around Chennai, East coast, Tamil Nadu.

\section{Materials and methods}

\section{Field work and sample collection}

For the present study, a total of 24 sediment samples were collected from different locations in diverse environments such as freshwater lakes, rivers, estuaries and sea around the Chennai metropolitan city, Tamil Nadu (Figure 2) using a Van Veen grab sampler and the sampling locations were marked using the Global Positioning System (GPS) . The samples were then packed in polyethylene packets, dried in the open air and in the oven at the $30^{\circ} \mathrm{C}$ prior to the laboratory analyses. The sediment samples were analysed for grain size distribution following the protocols put forward by Ingram $\mathrm{RL}^{22}$ at the Department of Geology, Anna University Chennai. For this purpose, 5 grams of sediment samples was taken and a pinch of sodium Hexa-metaphosphate as a dispersal agent was added to it and mixed well to avoid coagulation and also removal of organic coatings around the grains. Further, the mixture was washed in a 230 -ASTM mesh size. After washing, the separate sand fractions were poured into a pre-weighted beaker. The silt and clay content was transferred into a $1000 \mathrm{ml}$ measuring jar and was allowed to settle for 2 hour and 3 minutes. The $20 \mathrm{ml}$ solution was taken in a pipette from the range of $500-600 \mathrm{ml}$ and dried in pre-weighed beaker and represented clay fraction.

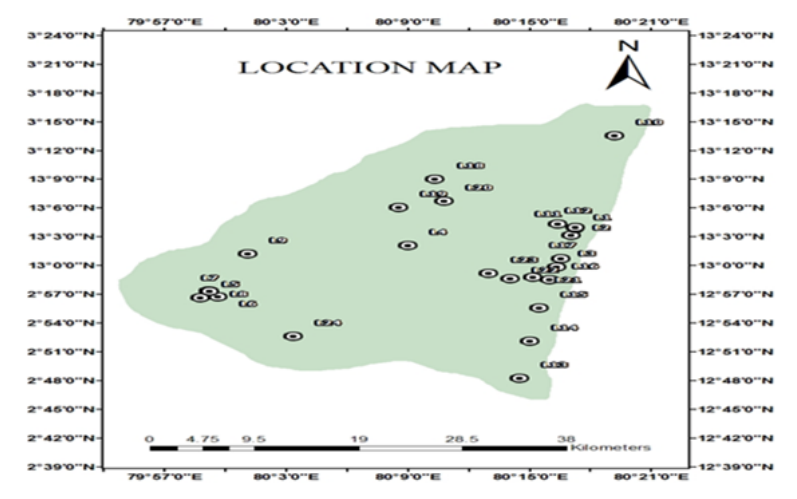

Figure 2 Location map of the sampling stations around Chennai region.

Total organic carbon (TOC) and total nitrogen (TN) were determined using about 1 gram of freeze-dried and weighed sediment, decarbonised with a $1 \mathrm{M}$ solution of hydrochloric acid, washed three times with deionised water, freeze-dried again and then analyzed in a Thermo Scientific Flash 2000 CHNS-O analyzer at the Department of Geology, Anna University, Chennai. The samples were weighed in Tin capsules, placed inside the auto sampler and then dropped into an oxidation/reduction reactor at a temperature of $950^{\circ} \mathrm{C}$.

For Diatom analyses, $20 \mathrm{ml}$ of $\mathrm{H}_{2} \mathrm{O}_{2}$ was added to $0.5 \mathrm{~g}$ of sediment sample. The samples were then heated at $90^{\circ} \mathrm{C}$ in a fuming cupboard until all the organic matter was oxidised (1-3) hours. The beaker with the sample was then removed from the heat and few drops of HCL $(50 \%)$ were added to remove the remaining $\mathrm{H}_{2} \mathrm{O}_{2}$. After the repeated centrifuge of the samples for about 10 minutes at 1500RPM, the ammonia solution $(1 \%)$ was added so that the clay present in the sample was removed. A few drops of the mixture was then placed on a glass slide and identified for the diatom species and counted. Representative species of the diatoms were then photomicrographed. The data on sediments and the diatoms collected were then contoured mapped using Arc-GIS 9.3 (ESRI Software Inc.) to understand the distribution pattern of the sediments. The interpolated data in the form of distribution maps were prepared using the Inverse Distance Weighted (IDW) method.

\section{Results}

The percentage of sand, silt and clay were plotted in Tri-plot diagram (Figure 3). The percentage of sand, silt and clay in the sediment samples collected from various stations around the city of Chennai varies from $9-98 \%, 0.8-56 \%$ and $0.7-64 \%$ respectively. The most of the lake sediments in Chennai are dominated by sand followed by silty sand, sandy silt and very few samples show the presence of silty clay and clayey silt. Based on the spatial distribution (Figures $4 \mathrm{~A}-4 \mathrm{C}$ ) of the sediments, the sand is dominated towards the coastal regions of Chennai particularly in the samples of LI, L2, L3, L4, L5, L10, L11, L13 , L14, L15, L16 and L17. The silty sand content is dominated in the samples of L6, L7, L8, L22, and L23. The sandy 
silt is found in the samples L9, L18 and L19 while at the sampled stations L12 and L21 silty clay and clayey silt sediments are abundant respectively.

TOC and TN in the sediment samples range between $0.15-3.50$ and 0.12-0.43 respectively. The TOC is high in sediment samples of L11, L12 and L21 where concentration of TOC was 3.43, 3.43 and 3.502 while as concentration of $\mathrm{TN}$ in sediment samples was 0.18 , 0.0 .12 and 0.19 respectively. The $\mathrm{C} / \mathrm{N}$ ratio in the sediment samples was highly variable. The $\mathrm{C} / \mathrm{N}$ ratio for most of samples falls below 4 . However, $\mathrm{C} / \mathrm{N}$ ratio of the samples collected from L20 and L24 show 7.18 and 8.48 respectively. The samples of few locations such as L11, L12 and L21 shows C/N ratio of 18.34, 26.656 and 18.14 respectively.

Diatom distribution shows a variety of species presently occurring in various environments around Chennai area (Figure 5). The Genus Cyclotella, Gyrosigma, paralia are the diatoms found in the estuarine environment while as Skeletonema, Grammatophra, Thalassiosira are abundant in marine environment. However, the genus Cymbella, Nitzchia, Fragilaria, Adlafia and Navicula are some of the common diatoms identified in the fresh water environments around the Chennai region.

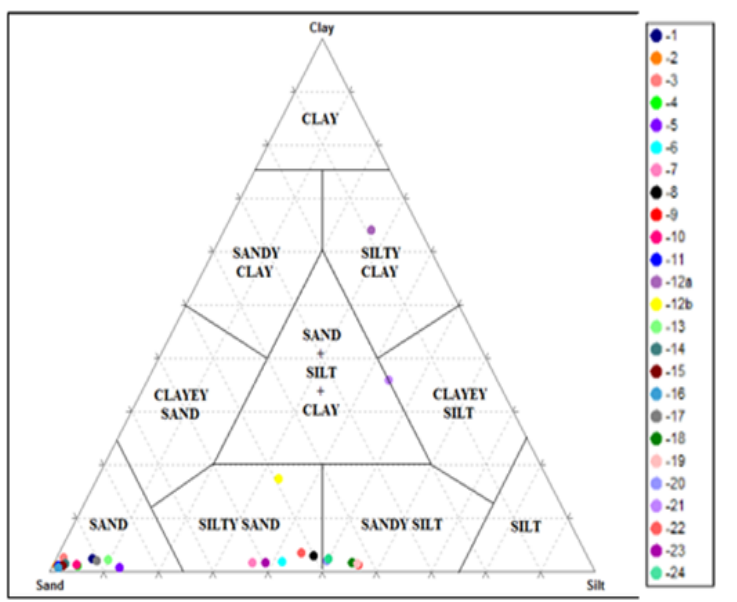

Figure 3 Ternary plot showing sand, silt and clay distribution in the sediment samples.

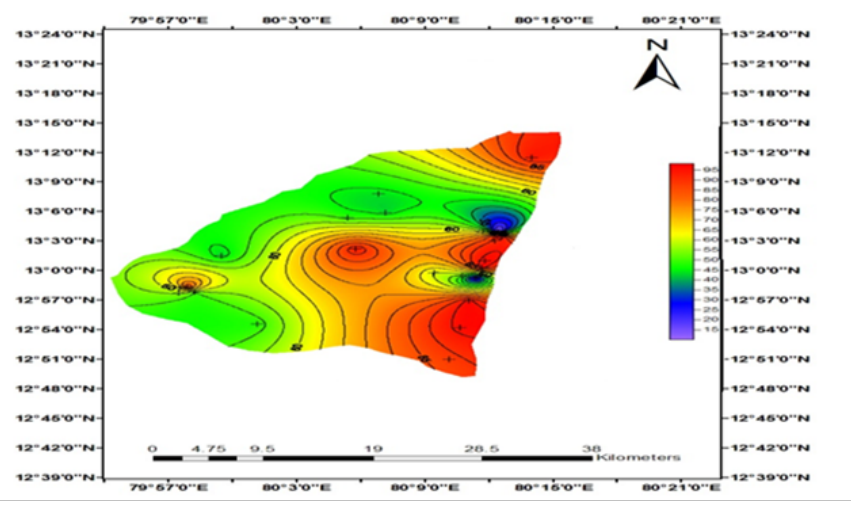

Figure 4A Spatial distribution map of sand content in sediment samples.

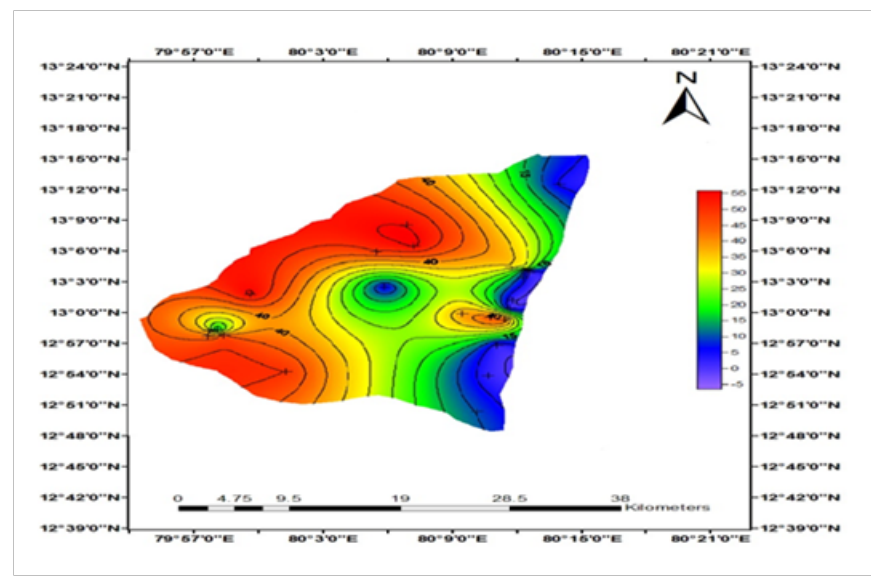

Figure 4B Spatial distribution map of silt content in the sediment samples analysed.

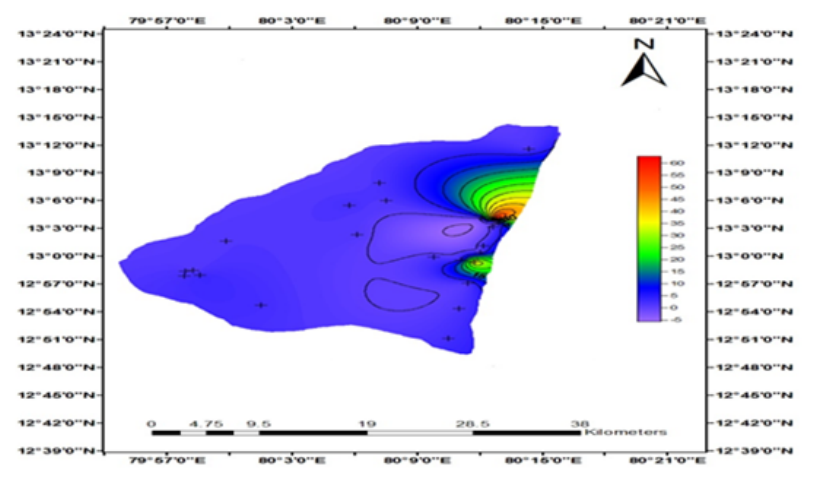

Figure 4C Spatial distribution map of clay content in sediment samples analysed.

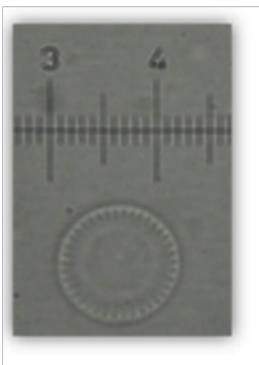

1.

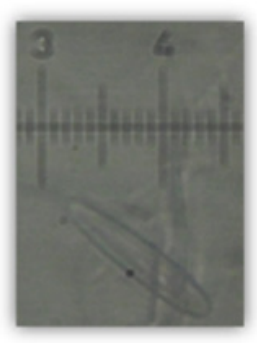

4.
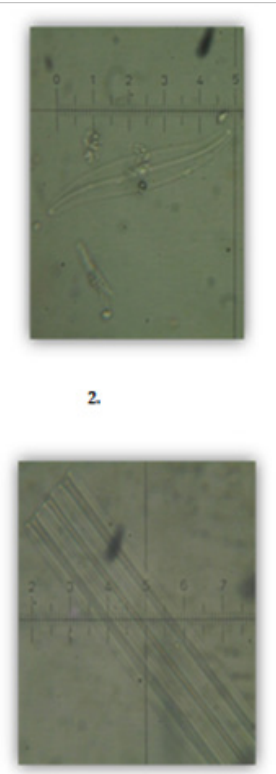

5.

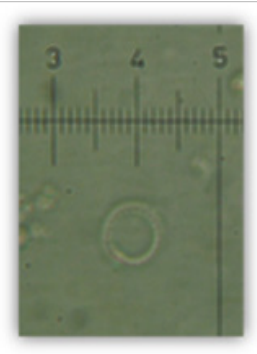

3.

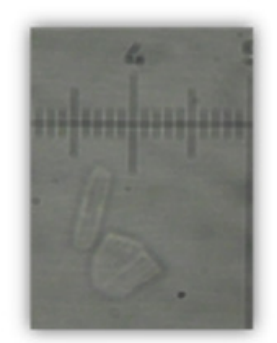




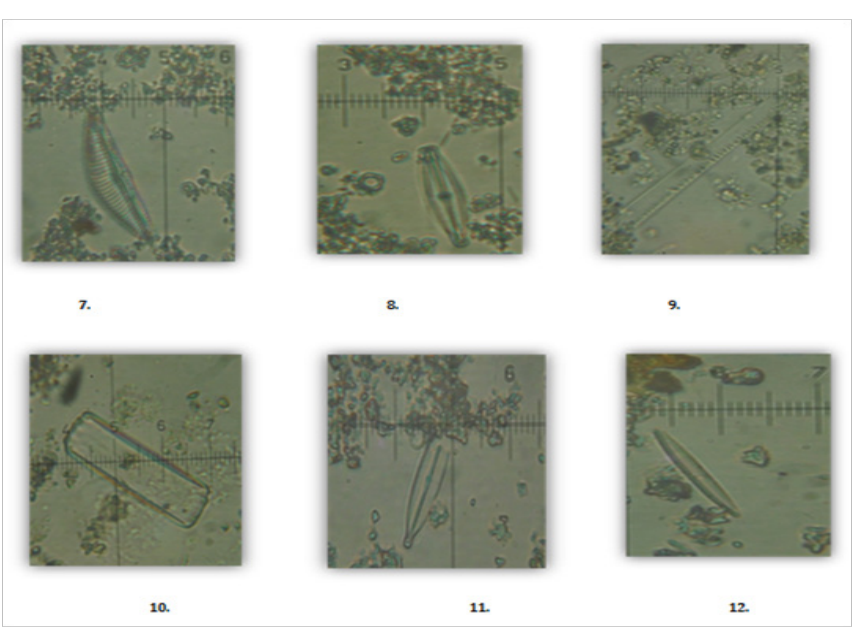

Figure 5 Diatoms found in the waters around Chennai (I. Cyclotella straita, 2. Gyrosigma acuminatum, 3. Paralia marina, 4. Skeletonema costatum, 5. Grammatophora oceanic, 6. Thalassiosira rotula, 7. Cymbella delicatula, 8. Cymbopleura amphicephala, 9. Nitzchia linearis, 10. Fragilaria hyaline, II. Adlafia muscora, 12. Fragilaria crotonensis).

\section{Discussion}

Our study on the distribution of $\mathrm{C} / \mathrm{N}$ ratio, diatom assemblage and relationship with catchment geomorphology provides a preliminary record on the modern environment and factors governing the distribution of various organic and inorganic components in different environments around the Chennai City. This information is important for the evaluation of further high resolution environmental and anthropogenic occurring in such habitats. The textural analyses of the sediment samples suggest that the sand and silty sand is mostly dominated in all the water bodies of Chennai. The coastal regions of Chennai show a very high concentration of sand in the sediment samples deposited by the ocean currents and waves. In Chembarambakkam Lake, Puzhal Lake and Ambattur Lake the sandy silt content reflects moderate energy regiment. Silty clay and clayey silt sediments dominate the Cooum River and Buckingham canal. The finer particles have been deposited due to the suspension and slackening processes and are an expression of the dispersion pattern and the current trend of sediment transport.

Most of the sediment samples show a $\mathrm{C} / \mathrm{N}$ ratio below 5 which indicates insitu source of organic carbon. Sediment samples collected from station L20 (Korattur Lake) and L24 (Manivakkam Lake) have a $\mathrm{C} / \mathrm{N}$ of 7.18 and 8.48 respectively indicating a mixed source of organic matter contribution. However, the sediment samples from location L11 (Cooum river mouth), L12 (Cooum river) and L21 (Buckingham Canal) show $\mathrm{C} / \mathrm{N}$ ratio above 12 , indicate terrestrial source of organic carbon. ${ }^{23}$ The sample of L11 (Cooum river mouth), L12 (Cooum river) and L21 (Buckingham Canal) also contain high content of the TOC in sediment samples that indicates relatively organically polluted sites. The $79.16 \%$ of locations show insitu source of organic matter, $8.3 \%$ of samples show mixed source of organic matter while as only $12.5 \%$ of samples show external source of organic matter in its samples. The bulk distribution of sand, silt, clay, TOC, TN and C/N is presented in Table 1. The Genus Cyclotella, Gyrosigma, paralia are the diatoms found in the estuarine environment while as Skeletonema, Grammatophra, Thalassiosira are abundantly present in marine environment, However Genus Cymbella, Nitzchia, Fragilaria, Adlafia and Navicula are some of the commonly observed diatoms present in fresh water environments in Chennai region. The species of diatom such as cyclotella has been assigned the Palmer organic pollution index of 1, while as Nitzchia and Navicula have assigned the index of $3 .{ }^{24}$ The abundance of these diatom species in estuaries and fresh water bodies of Chennai indicates that these fresh water bodies are being polluted by organic inputs and non-biodegradable materials and tasting brackish.

\section{Pearson correlation}

Pearson correlation matrix is used to investigate the dependence between multiple variables. The Pearson parametric correlation method was applied for the correlating the sediment parameters (Table 2). The sand shows strong positive correlation with TN and negative correlation with silt, clay, and $\mathrm{C} / \mathrm{N}$ ratio. This suggests similar source and ingress of TN with coarser sediments from the catchment areas. The clay shows strong positive correlation with TOC, $\mathrm{C} / \mathrm{N}$ and negative correlation with TN. This suggests that TOC and $\mathrm{C} / \mathrm{N}$ are interconnected and bound to the fine clay fractions. The TOC also shows negative correlation with $\mathrm{TN}$ and strong positive correlation with $\mathrm{C} / \mathrm{N}$ owing to the local sources. The $\mathrm{TN}$ shows strong negative correlation with $\mathrm{C} / \mathrm{N}$ signifying their different contributing sources. The preliminary data presented in this study reflect the spatial distribution and variation of OM, TOC and Diatom assemblages observed in the collected sediment samples. The results suggest that these environments are acquiring organic and inorganic pollutants owing to the large anthropogenic inputs and thus needs to be monitored and maintained for better ecological sustainability.

Table I Sampling station details with sand, silt and clay content with TOC,TN values and C/N ratio

\begin{tabular}{|c|c|c|c|c|c|c|c|c|c|c|}
\hline S. No. & I.D & Stations & Latitude (N) & Longitude (E) & $\begin{array}{l}\text { Sand } \\
\%\end{array}$ & Silt\% & Clay\% & TOC\% & TN\% & $\mathbf{C} / \mathbf{N}$ \\
\hline 1 & L1 & Marina Beach & $13^{\circ} 03^{\prime} 48.31^{\prime \prime}$ & $80^{\circ} 17^{\prime} 17.74^{\prime \prime}$ & 90.9 & 6.7 & 2.45 & 1.43 & 0.4 & 3.58 \\
\hline 2 & $\mathrm{~L} 2$ & Marina Beach & $13^{\circ} 03^{\prime} 14.01^{\prime \prime}$ & $80^{\circ} 17^{\prime} 06.05^{\prime \prime}$ & 98.1 & 0.8 & 1.1 & 1.41 & 0.38 & 3.75 \\
\hline 3 & L3 & Elliot's Beach & $12^{\circ} 59^{\prime} 55.20^{\prime \prime}$ & $80^{\circ} 16^{\prime} 22.55^{\prime \prime}$ & 96.2 & 1.2 & 2.6 & 1.573 & 0.44 & 3.61 \\
\hline 4 & L4 & Porur Lake & $13^{\circ} 02^{\prime} 08.39^{\prime \prime}$ & $80^{\circ} 09^{\prime} 03.73 "$ & 94.4 & 4.6 & 1.05 & 0.775 & 0.35 & 2.21 \\
\hline 6 & L6 & Pillaipakkam Lake & $12^{\circ} 56^{\prime} 50.01^{\prime \prime}$ & $79^{\circ} 59^{\prime} 40.92^{\prime \prime}$ & 56.35 & 41.7 & 1.9 & 1.891 & 0.18 & 1.24 \\
\hline 7 & L7 & Vangadu Pond & $12^{\circ} 57^{\prime} 21.16^{\prime \prime}$ & $79^{\circ} 59^{\prime} 18.92^{\prime \prime}$ & 62 & 36.3 & 1.65 & 0.392 & 0.32 & 1.24 \\
\hline 8 & L8 & Venkad Lake & $12^{\circ} 57^{\prime} 24.70^{\prime \prime}$ & $79^{\circ} 59^{\prime} 15.01^{\prime \prime}$ & 50 & 46.9 & 3.05 & 0.781 & 0.35 & 2.23 \\
\hline
\end{tabular}




\begin{tabular}{|c|c|c|c|c|c|c|c|c|c|c|}
\hline S. No. & I.D & Stations & Latitude (N) & Longitude (E) & $\begin{array}{l}\text { Sand } \\
\%\end{array}$ & Silt\% & Clay $\%$ & ТОС\% & TN\% & $\mathbf{C} / \mathbf{N}$ \\
\hline 9 & L9 & $\begin{array}{l}\text { Chembarambakm } \\
\text { Lake }\end{array}$ & $13^{\circ} 01^{\prime} 16.35^{\prime \prime}$ & $80^{\circ} 01^{\prime} 11.87^{\prime \prime}$ & 42.8 & 55.8 & 1.35 & 0.736 & 0.33 & 2.25 \\
\hline 10 & L10 & Ennore Creek & $13^{\circ} 13^{\prime} 35.77^{\prime \prime}$ & $80^{\circ} 19^{\prime} 13.57^{\prime \prime}$ & 94.4 & 4.35 & 1.3 & 1.023 & 0.41 & 2.48 \\
\hline 11 & L11 & Cooum river mouth & $13^{\circ} 04^{\prime} 03.46^{\prime \prime}$ & $80^{\circ} 17^{\prime} 19.13^{\prime \prime}$ & 97.8 & 1.05 & 1.15 & 3.43 & 0.19 & 18.35 \\
\hline 12 & $\mathrm{~L} 12$ & Cooum River & $13^{\circ} 04^{\prime} 23.95^{\prime \prime}$ & $80^{\circ} 16^{\prime} 27.67^{\prime \prime}$ & 9 & 26.8 & 64.15 & 3.412 & 0.13 & 26.66 \\
\hline 13 & L13 & $\begin{array}{l}\text { Muttukadu } \\
\text { Backwaters }\end{array}$ & $12^{\circ} 48^{\prime} 19.44^{\prime \prime}$ & $80^{\circ} 14^{\prime} 33.44^{\prime \prime}$ & 88.2 & 9.55 & 2.3 & 1.077 & 0.42 & 2.54 \\
\hline 14 & L14 & Uthandi Beach & $12^{\circ} 52^{\prime} 09.82^{\prime \prime}$ & $80^{\circ} 15^{\prime} 02.81^{\prime \prime}$ & 96.4 & 2.05 & 1.55 & 1.381 & 0.41 & 3.37 \\
\hline 15 & L15 & Olive Beach & $12^{\circ} 55^{\prime} 38.79^{\prime \prime}$ & $80^{\circ} 15^{\prime} 30.12^{\prime \prime}$ & 97.7 & 1.75 & 1.2 & 1.279 & 0.36 & 3.55 \\
\hline 16 & L16 & Thiruvanmiyur Beach & $12^{\circ} 58^{\prime} 36.81^{\prime \prime}$ & $80^{\circ} 16^{\prime} 03.01^{\prime \prime}$ & 98.1 & 1.2 & 0.7 & 1.32 & 0.39 & 3.38 \\
\hline 17 & L17 & Adyar Broken Bridge & $13^{\circ} 00^{\prime} 45.59^{\prime \prime}$ & $80^{\circ} 16^{\prime} 33.92^{\prime \prime}$ & 90.3 & 7.75 & 1.95 & 1.31 & 0.37 & 3.54 \\
\hline 18 & L18 & Puzhal Lake & $13^{\circ} 09^{\prime} 03.71^{\prime \prime}$ & $80^{\circ} 10^{\prime} 24.15^{\prime \prime}$ & 43.7 & 54.7 & 1.62 & 0.75 & 0.44 & 1.88 \\
\hline 19 & L19 & Ambattur Lake & $13^{\circ} 06^{\prime} 07.82^{\prime \prime}$ & $80^{\circ} 08^{\prime} 35.71^{\prime \prime}$ & 42.9 & 55.6 & 1.39 & 0.423 & 0.35 & 1.96 \\
\hline 20 & L20 & Korattur Lake & $13^{\circ} 06^{\prime} 47.41^{\prime \prime}$ & $80^{\circ} 10^{\prime} 50.37^{\prime \prime}$ & 48.2 & 49.7 & 2.06 & 0.883 & 0.19 & 7.18 \\
\hline 21 & L21 & Buckingham Canal & $12^{\circ} 58^{\prime} 50.77^{\prime \prime}$ & $80^{\circ} 15^{\prime} 13.33^{\prime \prime}$ & 19.9 & 44.2 & 35.92 & 3.502 & 0.18 & 18.2 \\
\hline 22 & L22 & KalluKuttai Lake & $12^{\circ} 58^{\prime} 41.51^{\prime \prime}$ & $80^{\circ} 14^{\prime} 04.77^{\prime \prime}$ & 52.1 & 44.4 & 3.54 & 0.15 & 0.32 & 0.5 \\
\hline 23 & L23 & Velachery Lake & $12^{\circ} 59^{\prime} 13.87^{\prime \prime}$ & $80^{\circ} 13^{\prime} 02.58^{\prime \prime}$ & 59.6 & 38.7 & 1.68 & 0.138 & 0.26 & 0.53 \\
\hline 24 & L24 & Manivakkam Lake & $12^{\circ} 52^{\prime} 41.01^{\prime \prime}$ & $80^{\circ} 03^{\prime} 25.32^{\prime \prime}$ & 47.7 & 49.9 & 2.36 & 1.307 & 0.15 & 8.49 \\
\hline
\end{tabular}

Table 2 Correlation matrix for various sediment quality parameters

\begin{tabular}{lllllll}
\hline Sand & & Silt & Clay & TOC & TN & C/N \\
\hline Sand & 1 & - & - & - & - & - \\
Silt & $-.859 * *$ & 1 & - & - & - & - \\
Clay & $-.616^{* *}$ & 0.13 & 1 & - & - & - \\
TOC & -0.16 & -0.23 & $.664 * *$ & 1 & - & - \\
TN & $.546^{* *}$ & -0.37 & $-.485^{*}$ & $-.445^{*}$ & 1 & - \\
C/N & $-.410^{*}$ & -0.02 & $.827^{* *}$ & $.878^{* *}$ & $-.621^{* *}$ & 1 \\
\hline
\end{tabular}

**Correlation is significant at the 0.0 I level (2-tailed).

*Correlation is significant at the 0.05 level (2-tailed).

\section{Conclusion}

Textural analysis reveals that the sediment samples collected from diverse environments around Chennai are dominated by sand followed by silty sand, sandy silt. However, the L12 and L21 locations show dominance of silty clay and clayey silt sediments. The presence of $\mathrm{C} /$ $\mathrm{N}<9$ indicates the insitu source of organic matter except L11 (Cooum river mouth), L12 (Cooum river) and L18 (Buckingham Canal) which shows $\mathrm{C} / \mathrm{N}>18$ indicating terrestrial source of organic matter. The abundance of diatom species like Cyclotella striata, Navicula and Nitzchia linearis and high concentration TOC concentration in estuaries and fresh water bodies mainly in the samples of L11 (Cooum river mouth), L12 (Cooum river) and L21 (Buckingham Canal) indicates that these water bodies are highly polluted by organic inputs probably due to anthropogenic activities.

\section{Acknowledgements}

Asif Ali and Aasif Lone are thankful to Anna University, Chennai for Anna Centenary Research Fellowship (ACRF) that enabled to carry out this work. Rayees Shah is grateful to the DST, New Delhi for DST-PURSE fellowship. The authors thank the anonymous reviewers for their constructive comments and suggestions that helped in the presentation of the data and improvement of the text.

\section{Conflict of interest}

The author declares no conflict of interest.

\section{References}

1. Dodds WK, Robinson CT, Gaiser EE, et al. Surprises and insights from long-term aquatic data sets and experiments. Bioscience. 2012;62(8):709721.

2. Morgan RM, Bull PA. The use of grain size distribution analysis of sediments and soils in forensic enquiry. Science \& Justice. 2007;47(3):125135 .

3. Balamurugan P, Vasudevan S, Selvaganapathi R, et al. Spatial distribution of grain size characteristics and its role in interpreting the sedimentary depositional environment, Kodaikanal Lake, Tamil Nadu, India. Journal of Earth Science and Climate Change. 2014;5:5-8. 
4. Folk RL, Ward WC. Brazos river bar: a study in the significance of grain size parameters. Journal of Sedimentary Petrology. 1957;27(1):3-26.

5. Kaushal S, Binford MW. Relationship between $\mathrm{C}: \mathrm{N}$ ratios of lake sediments, organic matter sources, and historical deforestation in Lake Pleasant, Massachusetts, USA. Journal of Paleolimnology. 1999;22(4):439-442.

6. Mahapatra DM, Chanakya HN, Ramachandra T. C:N ratio of sediments in a sewage fed urban lake. International Journal of Geology. 2011;5(3):8692.

7. Davis RB. Paleolimnological diatom studies of acidification of lakes by acid rain: an application of quaternary science. Quaternary Science Reviews. 1987;6:147-163.

8. Mishra S, Gupta AK, Mishra MK, et al. Study on variation of diatoms in Gomati River at Jaunpur for forensic consideration. Journal of pharmacy and Biol. Sciences. 2016;11(4):59-62.

9. Round FE. Diatoms in river water-monitoring studies. Journal of Applied Physiology. 1991;3:129-145.

10. Patil JV, Ekhande AP, Padate GS. Water quality monitoring- study of seasonal variation of diatoms and their correlation with physiochemical parameters of Lotus Lake, Toranmal. Archives of Science Research. 2013;5(1):172-176.

11. Kobayasi H Mayama S. Most pollution tolerant diatoms of severely polluted rivers in the vicinity of Tokyo. Japanese Journal of Phycology. 1982;30:188-196.

12. Rey DL, Roux H, Van Rensburgl L, Vosloo A. On the use of diatom-based biological monitoring Part 2: A comparison of the response of SASS 5 and diatom indices to water quality and habitat variation. Water $S A$. 2008;34:61-69.

13. Vörösmarty CJ, McIntyre PB, Gessner MO, et al. Global threats to human water security and river biodiversity. Nature. 2010;467:555-561.

14. Schneider SC, Lawniczak AE, Picińska-Faltynowicz J, et al. Do macrophytes, diatoms and nondiatom benthic algae give redundant information? Results from a case study in Poland. Limnologica. 2012;42(3):204-211.
15. Mackay AW, Battarbee RW, Flower RJ, et al. Assessing the potential for developing internal diatom-based transfer functions for Lake Baikal. American Society of Limnology and Oceanography. 2003;48(3):11831192.

16. Mackay AW, Jones VJ Battarbee RW. Approaches to Holocene climate reconstruction using diatoms. Encyclopaedia of Quaternary Science. 2003;20:294-309.

17. Interlandi SJ, Kilham SS. Diatom chemistry relationships in Yellowstone Lake (Wyoming) sediments: Implications for climatic and aquatic processes research. American Society of Limnology and Oceanography. 2003;48(1):79-92.

18. Roberts D, McMinn A. Relationships between surface sediment diatom assemblages and water chemistry gradients in saline lakes of the Vest fold Hills, Antarctica. Antarctic science. 1996;4(2):331-341.

19. Milly PCD, Betancourt J, Falkenmark M, et al. Stationarity Is Dead: Whither Water Management. Science. 2008;319:573-572.

20. Krishnakumari B, Deepa K, Priya KV. A Review on Impact of land use over Water Bodies in Chennai. International journal of emerging trends in Science \& Technology. 2016;3:255-260.

21. Gowri VS, Ramachandran S, Ramesh R, et al. Application of GIS in the study of mass transport of pollutants by Adyar and Cooum Rivers in Chennai, Tamilnadu. Environmental monitoring and assessment. 2007;138(1-3):419.

22. Ingram RL. Procedures in sedimentary petrology. New York, USA: Willey Interscience; 1970.

23. Meyers PA, Ishiwatari R. Lacustrine organic geochemistry- An overview of indicators of organic matter sources and diagenesis in lake sediments. Organic Geochemistry. 1993;20(7):867-900.

24. Kshirsagar AD. Use of algae as bioindicators to determine water quality river Mula from Pune city Maharashtra (India). Universal journal of environmental research and technology. 2013;3(1):79-85. 